\title{
O conceito de 'moderno Príncipe' - aplicando o contextualismo social na leitura dos Cadernos do Cárcere
}

Geraldo Magella Neres ${ }^{1}$

\begin{abstract}
Resumo: A proposição gramsciana do 'moderno Príncipe', como a maioria dos conceitos elaborados por Gramsci nos Cadernos do cárcere, sempre esteve aberta a polêmicas interpretativas. A causa dessas controvérsias exegéticas tem origem em dois fatores principais, no caráter fragmentário dos escritos carcerários e no método de trabalho empregado por Gramsci, baseado na apropriação crítica de algumas concepções produzidas fora da tradição marxista, modificando os seus conteúdos originais e assimilandoas em seu projeto de atualização da 'fillosofia da práxis'. O objetivo deste artigo é apresentar a proposição do 'moderno Príncipe', mostrando que, apesar de fragmentária, existe uma teoria do partido nos Cadernos do cárcere. Em seguida, recorrendo às novas categorias políticas elaboradas por Gramsci, esta teoria do partido é apresentada de forma sistematizada.
\end{abstract}

Palavras-chave: Gramsci; Teoria Política; Moderno Príncipe; Partido Revolucionário.

\section{The concept of 'modern Prince' - a contextualized reading of Prison Notebooks}

\begin{abstract}
The Gramscian proposition of the 'modern prince', like most of Gramsci's concepts in the Prison Notebooks, has always been open to interpretative polemics. The cause of these exegetical controversies stems from two main factors, the fragmentary character of prison writings and the method of work employed by Gramsci, based on the critical appropriation of some conceptions produced outside the Marxist tradition, modifying their original contents and assimilating them into his project to update the 'philosophy of praxis'. The purpose of this paper is to present the 'modern prince' proposition, showing that, although fragmentary, there is a party theory in the Prison Notebooks. Then, using Gramsci's new political categories, this party theory is presented in a systematic way.
\end{abstract}

Palavras-chave: Gramsci; Political theory; Modern Prince; Revolutionary party.

\footnotetext{
${ }^{1}$ Graduado em Ciências Sociais (UNESP/Marília), Mestre e Doutor em Ciências Sociais (UNESP/Marília), professor no curso de Ciências Sociais na Unioeste, Campus de Toledo. E-mail: geraldomagellaneres@yahoo.com.br
} 


\section{Introdução}

A proposição gramsciana do 'moderno Príncipe', como a maioria dos conceitos elaborados por Gramsci nos Cadernos do cárcere, sempre esteve aberta a polêmicas interpretativas. A causa dessas controvérsias exegéticas tem origem em dois fatores principais, mas não únicos, como veremos mais adiante. Primeiro, no caráter fragmentário, disperso e "inacabado" ou "em construção" do texto carcerário, apesar da tentativa preliminar de sistematização feita pelo autor entre os anos de 1931 e 1935 , quando transcreveu suas notas esparsas para cadernos especiais abordando um único tema. $\mathrm{Na}$ verdade, o que Gramsci fez neste período foi passar a limpo as suas notas, modificando algumas, mantendo a forma original de outras e agrupando-as em torno de uma temática específica. Porém, é evidente que o resultado alcançado ainda ficou muito aquém da forma exigida de um texto para publicação. Mas essa, como se sabe, não era a intenção de seu autor. Em segundo lugar, a controvérsia interpretativa também é alimentada pelo método de trabalho empregado por Gramsci, baseado na apropriação crítica de algumas concepções produzidas fora da tradição marxista, modificando os seus conteúdos originais e assimilandoas em seu projeto de atualização da 'filosofia da práxis'.

Assim, de imediato, convém estabelecer os modos principais de enquadramento da leitura do conceito de 'moderno Príncipe' postulados pela comunidade de intérpretes. Segundo a classificação proposta por Peter Thomas (2017, p. 1-2), pode-se identificar, ao longo da cronologia dos estudos gramscianos, três concepções distintas da metáfora do 'moderno Príncipe': 1) "um "código" para Partido Comunista", tanto em sua versão "'leninista" quanto como uma alternativa "marxista ocidental"”, 2) "como uma descrição genérica do moderno partido político como tal" e 3) como um símbolo da "encarnação do poder político que se consolidou no início do século XX", instituindo a "noção de poder político como auto fundacional, em vez de legitimado pela tradição (moral ou institucional) ou consenso (subjetivo)".

Esta classificação evidencia um nítido movimento de deslocamento da interpretação da obra gramsciana em relação à historicidade de seu autor. O polemista de fôlego da imprensa operária, o quadro político da Internacional Comunista e o principal líder do PCd'I entre 1924/26 é progressivamente transformado numa espécie de teórico da política em geral. Este processo pode ser acompanhado analisando-se as modificações na perspectiva de enquadramento da leitura da obra de Gramsci. Inicialmente, assim que a obra carcerária veio a público, ainda na velha edição temática organizada por Palmiro Togliatti e Felice Platone, publicada em seis volumes entre 1948 e 1951, prevaleceu a compreensão de que a expressão 'moderno Príncipe' nada mais seria do que uma cifra para designar o modelo de partido marxista-leninista então vigente na época. A hegemonia estalinista do movimento comunista internacional e a relativa codificação da escrita carcerária forneceram os elementos ideológicos e objetivos dessa primeira interpretação. Num segundo momento, assim que se arrefeceu a influência do estalinismo, ao mesmo tempo que foi publicada a edição crítica dos Cadernos do cárcere (1975) ${ }^{2}$, a proposta do 'moderno Príncipe' cada vez mais passou a ser entendida como uma superação positiva da concepção restritiva do partido de quadros marxista-leninista, designando uma forma organizativa adaptada às especificidades do processo revolucionário nas formações sociais do Ocidente.

O passo seguinte, na esteira do esvaziamento da perspectiva da revolução socialista, refletindo a integração dos partidos operários europeus no 'mercado eleitoral', resultou na compreensão da fórmula do 'moderno Príncipe' como uma representação da figura do partido eleitoral de massas, então reconhecido como o principal fiador da existência das democracias representativas. Finalmente, a partir da terceira fase de dissociação da historicidade da reflexão gramsciana, quando a derrota ideológica do movimento operário revolucionário chega a seu termo, o golpe de misericórdia foi dado pela interpretação que desvinculava a fórmula do 'moderno Príncipe' de qualquer referência à questão organizativa ou partidária. Ou seja, nesta nova perspectiva interpretativa, a metáfora do 'moderno Príncipe', já completamente apartada de seu contexto histórico original, passa a indicar uma vaga

2 A edição crítica, composta por quatro volumes, apresenta os Cadernos respeitando a cronologia de sua redação. 
elaboração teórica sobre as mutações da política e do poder ${ }^{3}$. Deste modo, uma obra organicamente vinculada à luta pela revolução socialista é transformada numa reflexão abstrata sobre as mutações da política durante as três primeiras décadas do século XX.

O objetivo deste artigo é apresentar a proposição do 'moderno Príncipe' a partir do primeiro enquadramento interpretativo. Contudo, parte-se da perspectiva de que a fórmula gramsciana refere-se a uma forma-partido distinta do modelo marxista-leninista, apontando para um tipo de organização revolucionária inovadora, resultante da tradução da concepção de partido presente nas "Teses de Lyon" no novo instrumental conceitual desenvolvido nos Cadernos do cárcere. Neste sentido, a proposição do 'moderno Príncipe' não se referia nem ao modelo sectário de partido proposto pelo estalinismo, nem, muito menos, indicaria uma fórmula abstrata e inefável de uma nova instauração do poder político. Como provam os instigantes embates travados por Gramsci nos Cadernos do cárcere, tanto com Maquiavel quanto com Robert Michels, fica evidente que o que ele buscou foi uma atualização da teoria marxista da organização às novas impostações da Ciência Política de sua época.

A aplicação do método de investigação do 'contextualismo social' ${ }^{4}$ às notas gramscianas dedicadas à proposição do 'moderno Príncipe' permite reivindicar uma continuidade ininterrupta na elaboração teórica gramsciana, unificando a sua militância prática pré-carcerária com a reflexão mais abstrata do período carcerário. Então, a fórmula do 'moderno Príncipe' pode ser apreendida como a conformação final de uma teoria original da forma-partido que vinha sendo desenvolvida desde o período imediatamente anterior à sua prisão, quando da elaboração das "Teses de Lyon" e de sua experiência como secretário-geral do PC d'I. E é isso que pretendo demonstrar aqui ${ }^{5}$, primeiro (i) reivindicando que, apesar de fragmentária (mais implícita do que explícita), existe uma teoria do partido nos Cadernos do cárcere. Em seguida, (ii) recorrendo às novas categorias políticas elaboradas por Gramsci, pretendo sistematizar este conjunto de notas numa concepção de partido minimamente articulada.

\section{Abordagem teórico-metodológica - em busca do 'moderno Príncipe'}

\section{Como ler a teoria política gramsciana?}

A leitura da teoria política gramsciana, mais especificamente de sua concepção de 'moderno Príncipe', pode ser feita de diferentes perspectivas metodológicas. Basicamente, hoje, no contexto da academia, distinguimos duas vertentes principais ou dois tipos de contextualismos metodológicos utilizados na prática exegética: o ‘contextualismo linguístico' e o ‘contextualismo social'. Além dessas duas abordagens metodológicas existe, quase que restrita somente à análise filosófica, e utilizada mais como uma técnica de leitura ${ }^{6}$ do que propriamente como um método de investigaşão de textos - a abordagem textualista ou "textualismo". Escolher uma dessas metodologias significa adotar uma visão de mundo sistemática do significado do texto de teoria política, de suas especificidades, de seus nexos sociais, do processo de interpretação etc. Enfim, significa a adoção de um 'quadro teórico' consistente sobre a localização do texto no interior da dinâmica social na qual foi produzido.

\footnotetext{
3 “O moderno Príncipe é o nome deste novo projeto de pesquisa, no qual Gramsci expande sua concepção do partido político para significar não apenas uma instituição, uma forma ou um sujeito, mas um processo de totalização da reforma moral e intelectual, ou uma "política de outro tipo"” (THOMAS, 2017, p. 7).

4 Trata-se do método de leitura proposto por Neal Wood e Ellen Wood (conferir WOOD, 1978).

5 Para uma apresentação mais exaustiva da teoria gramsciana do 'moderno Príncipe', partindo de uma perspectiva metodológica distinta (leitura filológica), consultar Neres (2012). O que se pretende aqui é uma investigação da teoria política gramsciana por meio da aplicação do 'contextualismo social'.

6 Há controvérsias sobre isso, já que alguns estudiosos consideram a "análise textual” ou "textualismo" (principalmente na versão proposta por Leo Strauss) como um método de leitura (quadro teórico sistemático sobre a produção do texto e de sua análise hermenêutica) e não uma técnica de leitura. Sobre esta questão, conferir Silva (2019).
} 
Por conseguinte, a aplicação da metodologia do 'contextualismo social' à interpretação do conceito de 'moderno Príncipe' alicerça-se em cinco postulados fundamentais ${ }^{7}$. Em primeiro lugar, no reconhecimento do estatuto prático da atividade política. $\mathrm{Na}$ aceitação legítima de que a política lida diretamente com os interesses práticos das diversas classes sociais, das frações de classes ou de grupos sociais mais restritos. Neste sentido, a prática política como entendida/exercida por Gramsci sempre esteve voltada para a defesa dos interesses das 'classes subalternas' ou das classes populares. Em segundo lugar, no reconhecimento positivo da relação da teoria política gramsciana (e, em última instância, de sua proposição do 'moderno Príncipe') com o contexto histórico das primeiras décadas do século XX. Dizer isso significa reconhecer que, para Gramsci, assim como para milhares, senão milhões de seres humanos ao redor do mundo naquele momento, a revolução socialista estava na ordem do dia. Consequentemente, a teoria política gramsciana está visceralmente vinculada à perspectiva da revolução socialista, procurando descobrir os princípios táticos e estratégicos que pudessem favorecer a ascensão do proletariado italiano ao poder.

Em terceiro lugar, complementando o segundo pressuposto, pode se afirmar que essa teoria política produzida por Gramsci é, de uma forma mais ou menos mediada, um reflexo ou um testemunho vivo daquela dinâmica social que contrapôs classes sociais, partidos políticos, Estados e intelectuais diante de visões de mundo antagônicas (capitalismo versus socialismo ou liberalismo versus marxismo). Em quarto lugar, como desdobramento lógico dos pressupostos anteriores, fica evidente o caráter partidário da obra de Gramsci, de seu posicionamento intransigente na defesa dos interesses do proletariado italiano e mundial. E, finalmente, coroando toda a argumentação precedente, o quinto pressuposto afirma o reconhecimento do caráter ideológico da obra gramsciana, já que toda obra de teoria política não pode deixar de não ser um misto de conhecimento filosófico-científico e de estímulo à ação ou de intervenção na conjuntura. Ou seja, assim fica mais do que evidente que também a teoria política, mesmo sendo teoria, ainda é uma forma de intervenção prática no conflito social; isto é, a teoria política também é uma forma específica de práxis.

Com efeito, da aplicação desses postulados epistemológicos decorrem três procedimentos operacionais que fundamentaram a minha leitura da teoria política gramsciana. O primeiro procedimento operacional consiste em reconhecer a unitariedade entre atividade política prática e reflexão teórica na vida de Antonio Gramsci. Esta unitariedade, ou ausência de segmentação entre militância política e reflexão teórica, é muito anterior ao período carcerário, remontando aos primórdios de sua atividade política, quando militância e jornalismo se unificaram pela primeira vez. O que muda nos escritos carcerários é que ali a prática política anterior é que passa a fornecer a matéria-prima para uma reflexão mais universal.

O segundo procedimento operacional consiste na identificação da continuidade da elaboração da teoria do partido na reflexão de Gramsci, constatando uma evolução orgânica entre a teoria do partido sistematizada nas "Teses de Lyon" e aquela presente nos Cadernos do cárcere. Finalmente, o terceiro procedimento operacional, decorrência direta dos anteriores, assegura que é exatamente no texto carcerário, quando Gramsci elabora um novo quadro conceitual (atualização da 'filosofia da práxis'), construído a partir de seu acerto de contas com suas fontes formadoras e com a experiência prática da derrota do movimento operário italiano diante do fascismo, que a sua teoria do partido revolucionário atinge o seu desenvolvimento máximo, exatamente por meio da proposição do 'moderno Príncipe'.

\footnotetext{
7 Esses pressupostos que fundamentam a metodologia do 'contextualismo social' foram delineados por Neal Wood (1978, p. 345). Aqui, no processo de leitura da obra de Gramsci, o que se busca é a operacionalização destes pressupostos.
} 


\section{O partido antes dos Cadernos do cárcere - as primeiras formulações sistemáticas}

Em pouco mais de dois anos à frente do PC d'I, desde sua eleição para o cargo de secretário-geral em agosto de 1924 até a sua prisão em novembro de 1926, Gramsci reformulou profundamente a organização e a estratégia do partido herdadas da direção bordighista. Neste meio tempo, quando o PC d'I se caracterizou como um partido efetivamente gramsciano, a sua reflexão centrou-se na investigação da realidade social da península, buscando construir uma estratégia capaz de recolocar o partido no centro da cena política italiana. Apesar do aumento da repressão fascista, e da situação de clandestinidade do partido, pode-se dizer que Gramsci obteve um relativo sucesso, já que conseguiu fazer com que a organização continuasse funcionando.

Neste momento, dada a situação de confronto, a reflexão de Gramsci volta-se inteiramente para a construção de uma estratégia revolucionária realista, buscando assegurar a eficácia da intervenção política do partido e a identificação dos possíveis sujeitos da revolução na Itália. Como dirigente máximo do partido, mais do que nos períodos anteriores, a reflexão de Gramsci dirige-se primordialmente à intervenção política. O ethos da possibilidade da revolução socialista, que é fundamental para a compreensão do pensamento de Gramsci, torna-se muito mais evidente neste momento. Neste sentido, a principal tarefa desempenhada por Gramsci foi assegurar a eficácia da intervenção dos comunistas no processo de luta de classes aberto na Itália. Esse esforço pode ser desdobrado em duas ações principais: na substituição da ideologia determinista herdada do primeiro grupo dirigente do PCd'I e na reestruturação organizativa do partido.

Quanto à primeira ação, o problema mais urgente enfrentado por Gramsci foi a substituição da concepção fatalista do processo revolucionário, de viés econômico determinista, fortemente difundida entre os quadros dirigentes do partido, substituindo-a por uma concepção dialética da revolução que priorizasse a correlação entre possibilidade objetiva e capacidade efetiva de intervenção por parte do partido. Quanto à questão organizativa, Gramsci procurou romper radicalmente com o modelo sectário de organização construído por Bordiga, estruturado como uma seita isolada ou como um "órgão" de classe para alicerçar o PCd'I no movimento de resistência ao fascismo. Em suma, Gramsci buscou transformar o partido numa "parte" da classe, aquela politicamente mais consciente e ativa. Consequentemente, essa mudança organizativa exigia a transformação do PC d'I, antes um partido de quadros, num autêntico partido de massas. Pode-se dizer que este foi o período de maior esforço de Gramsci na retomada da capacidade de atuação organizada do partido: ele empenha todas as suas capacidades físicas e intelectuais nesse processo, participando de reuniões infindáveis, de discussões polêmicas etc.

Com efeito, é neste momento que as ideias que Gramsci vinha debatendo com seus companheiros mais próximos entre 1923 e 1924, no contexto da crítica feita à concepção fatalista de partido defendida por Bordiga, ganham certa sistematicidade. Isso fica muito evidente em dois textos produzidos no período: as "Teses de Lyon" (redigidas junto com Togliatti e outras lideranças entre agosto e setembro de 1925) e o ensaio inacabado intitulado A questão meridional (provavelmente de outubro de 1926). Esses dois documentos são importantes por uma série de fatores, mas, principalmente, porque fornecem o primeiro esboço da concepção de partido que Gramsci desenvolverá mais tarde, já nos escritos carcerários, sob a rubrica do 'moderno Príncipe'. Esses dois textos fornecem o fio condutor que permite unificar a concepção de partido esboçada antes da prisão com aquela que será desenvolvida nos Cadernos do cárcere.

O primeiro passo dado por Gramsci foi identificar na formação social italiana os possíveis sujeitos políticos da revolução socialista. Conforme sua investigação, as forças motrizes do processo revolucionário italiano seriam: "1) a classe operária e o proletariado agrícola" e "2) os camponeses do Sul e das Ilhas e os camponeses das demais partes da Itália" (GRAMSCI, 2004, p. 337). Fica evidente a centralidade do campesinato, ao lado do proletariado industrial, na conformação do sujeito revolucionário, segundo a concepção das “Teses de Lyon". Essa percepção permanece forte também nos 
Cadernos do cárcere, a única diferença é que nos escritos carcerários ocorre uma mudança na terminologia, pois Gramsci acaba por adotar a expressão 'classes subalternas' para se referir a essa aliança operáriocamponesa.

Neste momento, o partido aparece como o instrumento fundamental de preparação e de condução do processo revolucionário. Este modelo de partido, de clara inspiração leninista, estaria inteiramente comprometido com a revolução proletária, devendo exercer sobre a sua referência social uma tarefa dupla: 1) construir uma identidade política autônoma entre o proletariado e seus aliados e 2) apresentar-se/fazer-se reconhecido como o único fiador dos interesses das classes populares, guiando-as no processo de conquista do poder. Curiosamente, esse projeto gramsciano de reorganização do PCd'I foi concebido sob o influxo da palavra de ordem da IC de "bolchevização" dos partidos comunistas surgidos da cisão com o reformismo socialdemocrata. Digo curiosamente porque a concepção gramsciana do partido, mesmo que inspirada na política de "bolchevização", ficou muito distante daquele modelo sectário de partido marxista-leninista, que logo se tornaria hegemônico no movimento comunista internacional por imposição da IC.

O núcleo da proposta gramsciana de reestruturação do PCd'I constava de quatro "pontos fundamentais". O primeiro ponto propunha a substituição do sectarismo esquerdista de Bordiga, ainda muito influente entre parte dos quadros dirigentes, por uma concepção dialética de partido e de revolução, profundamente inspirada na elaboração teórico-prática leniniana. O segundo ponto, de caráter organizativo, visava adequar a atuação do partido às condições específicas da clandestinidade, sem abrir mão de uma "estrutura organizativa de massa". Neste caso, tratava-se de romper com o isolacionismo político do primeiro grupo dirigente, assegurando um mínimo de coesão interna e de eficácia da intervenção do partido na luta política das massas populares. O terceiro ponto, que girava em torno da modificação do "elemento de base" da organização partidária, visava introduzir a "célula" baseada no local de trabalho como fundamento da estruturação do partido. E, por último, o quarto ponto propunha o rompimento definitivo com o esquerdismo catastrofista e seus princípios táticos abstratos, assentado as definições táticas no terreno da análise das condições objetivas da conjuntura política e na correlação de forças entre as classes em luta (GRAMSCI, 2004, p. 342).

Da confluência desses quatros pontos resulta um modelo de partido muito bem definido. A estrutura organizativa o qualificava como um partido de massas, mesmo que na realidade, em função da repressão fascista, não contasse com um grande número de militantes. A substituição do sectarismo bordighista pelo leninismo, no contexto da apropriação criativa da bolchevização feita por Gramsci, promoveu uma melhora significativa na elaboração tática e na eficácia da intervenção do partido nas diversas frentes da luta popular contra o fascismo. E a introdução da "célula" como elemento de base da organização partidária, ainda que somente iniciada, produziu um grande número de lideranças partidárias extraídas diretamente da classe operária, garantido a preponderância dos elementos proletários na direção do partido.

Este conjunto de medidas, considerando-se os limites para a sua efetiva implementação, dadas as dificuldades oriundas da clandestinidade, conformaram a teoria gramsciana do partido antes do seu encarceramento. Então, ainda acreditando na viabilidade da tática bolchevique de assalto direto ao poder de Estado, Gramsci acaba enredado em seu próprio horizonte histórico, até perceber, depois da prisão, que a nova determinação do Estado vigente na Europa ocidental exigia não só uma profunda reformulação tático-estratégica, mas também a conformação de uma nova forma-partido adequada para a luta política no Ocidente. 


\section{O 'moderno Príncipe' - uma categoria intertextual}

A prisão de Antonio Gramsci, então deputado e secretário-geral do PCd'I, em 08 de novembro de 1926, demarca uma mudança profunda em sua elaboração política teórico-prática. Até este momento Gramsci ainda acreditava na possibilidade de aplicação no Ocidente da estratégia revolucionária utilizada vitoriosamente pelos bolcheviques no Oriente. A partir do momento da prisão - como já prenunciado no último texto importante escrito em liberdade (A Questão Meridional) - Gramsci cada vez mais se dá conta de que existem diferenças estruturais entre as formações sociais do Oriente e do Ocidente que impõem a escolha de estratégias revolucionárias distintas. A principal descoberta de Gramsci é que na Europa/Ocidente o Estado teria reservas de forças que não possuiria na Rússia/Oriente, colocando a necessidade da construção da hegemonia do proletariado sobre as classes populares como pressuposto fundamental da ruptura revolucionária (GRAMSCI, 2004, p. 378).

Assim, as notas que Gramsci elabora na prisão, que irão constituir os Cadernos do cárcere, buscam, sobretudo, compreender uma questão essencial: por que a revolução socialista, vitoriosa na Rússia, fracassou na Europa ocidental? Contudo, Gramsci se dispõe a empreender tal investigação a partir de uma perspectiva metodológica bastante original. Ou seja, recusando seguir a trilha do determinismo economicista que dominava o marxismo da época, o dirigente sardo se propõe a buscar uma solução híbrida, estabelecendo uma interlocução crítica em duas frentes: i) assimilando os desenvolvimentos teóricos e práticos do movimento comunista internacional, principalmente aqueles advindos do leninismo e ii) apropriando-se criticamente das novas aquisições da filosofia europeia de meados da primeira metade do século XX. É neste contexto que se enquadra a sua reflexão sobre o partido revolucionário, que agora é amplamente expandida, atendendo à necessidade de incorporar a investigação sobre a construção da hegemonia nas formações sociais marcadas pela presença do 'Estado integral' ou 'ampliado'. Desta forma, a discussão transcende o formalismo anterior na caracterização do partido revolucionário, que deixa de significar meramente o aparelho organizativo para indicar uma concepção nova, centrada na ideia do partido como um processo mais abrangente de construção de uma nova hegemonia. Assim surge a proposição do 'moderno Príncipe'.

Mas, convém indagar, existe uma teoria do partido nos Cadernos do cárcere?

Como já salientado anteriormente, a especificidade da escrita carcerária não produziu uma elaboração teórica sistemática como é costume num texto acadêmico destinado à publicação, onde as categorias conceituais são rigorosamente definidas e delimitadas. Diante das vicissitudes das condições do encarceramento e de algumas características do próprio método de trabalho de Gramsci, a sua escrita assumiu a feição de uma obra aberta ou de um trabalho em construção, profundamente marcada pela fragmentação. Como resultado disto, o significado das categorias que compõem o seu novo quadro conceitual não é evidente por si, nem fica explícita a vinculação de sua elaboração teórica carcerária com aquela do período anterior à prisão. Em função disto, a compreensão adequada de seus conceitos exige um trabalho minucioso de reconstrução histórico-filológica. E é isto que a comunidade de estudiosos da obra gramsciana vem fazendo, pelo menos desde a publicação da edição crítica dos Cadernos do cárcere por Valentino Gerratana e equipe na segunda metade da década de setenta do século passado.

Mais especificamente, já que o que nos interessa é a proposição do 'moderno Príncipe', pode-se dizer que inexiste nos Cadernos do cárcere uma teoria sistemática sobre o partido revolucionário. Ou seja, falta uma definição rigorosa da função, organização e estratégia da forma-partido identificada pela rubrica do 'moderno Príncipe'. Enfim, como a maioria das categorias elaboradas nos escritos carcerários, o conceito de 'moderno Príncipe' deve ser extraído da articulação de um vasto conjunto de notas que abordam a ação política, a interpretação de Maquiavel, a crítica do 'centralismo burocrático', a composição social dos partidos políticos, o teorema das proporções definidas, a crítica a Michels etc. O Caderno 13, que é um caderno temático dedicado à proposição do 'moderno Príncipe', é aquele que aborda de modo mais extensivo o assunto. Entretanto, está muito distante de um tratamento ordenado sobre a questão do partido revolucionário, apenas apresentando reflexões episódicas e fragmentárias sobre a 
organização partidária. Além do Caderno 13, essas notas aparecem ainda em vários outros cadernos, destacando-se os cadernos 4, 8, 14, 15 e 18.

Contudo, se falta uma teoria sistemática do 'moderno Príncipe', ela existe como uma virtualidade. Ou melhor, dada a persistência do tema do partido, e de sua refração num grande número de notas dos Cadernos que abordam temáticas próximas, o texto gramsciano acaba por sugerir uma teoria implícita do 'moderno Príncipe'. Porém, não uma teoria expressa formalmente, já que esta é muito mais o resultado da intertextualidade criada pelos temas conexos tratados pelo autor. Assim, a interação dessa multiplicidade de notas, abordando questões direta ou indiretamente ligadas à teoria da organização política, aliada ao estudo da elaboração sistemática do partido presente nas "Teses de Lyon", pode ajudar na recuperação do conteúdo do conceito de 'moderno Príncipe'. Por conseguinte, apesar da fragmentariedade discursiva, a leitura "contextualizada" destas notas aponta para a proposição de uma forma-partido bastante original. É neste ponto que o 'contextualismo social' pode ajudar a reconstruir o conceito de 'moderno Príncipe', pois pode preencher os hiatos produzidos pela fragmentação da escrita carcerária.

Disso tudo resulta que a teoria do 'moderno Príncipe' presente in nucce nos Cadernos do cárcere aparece visceralmente fundida ao novo universo categorial criado por Gramsci para investigar a especificidade da revolução comunista no Ocidente. Aliás, indo além, pode-se afirmar que essa versão final de sua teoria do partido - isto é, do partido enquanto uma encarnação do príncipe moderno - só pode ser adequadamente extraída se situada no contexto deste novo quadro conceitual construído como um projeto de atualização do marxismo.

\section{O 'Estado ampliado' como horizonte de atuação do 'moderno Príncipe'}

O que distingue o Ocidente do Oriente é a presença de uma nova determinação histórica do Estado. A investigação desta importante distinção na estruturação do poder político nas formações sociais capitalistas desenvolvidas - agora fundado na articulação dinâmica entre coerção e consenso, e não mais apenas na coerção - está no centro da reflexão realizada por Gramsci nos Cadernos do cárcere.

Essa divergência na estruturação do poder político nas sociedades capitalistas é apreendida por Gramsci por meio da utilização de uma metáfora geopolítica de contraposição entre Oriente e Ocidente. No entanto, esta discrepância aparentemente espacial, que confrontava duas regiões geográfico-culturais, acaba por se revelar como sendo eminentemente histórica, já que serve principalmente para indicar os níveis diferenciados de complexidade das sociedades capitalistas desenvolvidas diante daquelas mais "atrasadas" ou pouco desenvolvidas. Assim, por meio deste contraste histórico, Gramsci acaba identificando uma nova morfologia do Estado capitalista, qualificada por ele de 'Estado integral' (GRAMSCI, 2001, p. 691).

Com efeito, o conceito de 'Estado integral' ou 'ampliado' redefine toda a elaboração política que Gramsci vinha desenvolvendo até o momento de sua prisão. Por um lado, a proposição do conceito de 'Estado integral' está no cerne do projeto gramsciano de atualização da 'fillosofia da práxis', modelando a conformação de um novo quadro teórico-conceitual necessário para se pensar a prática política revolucionária na Itália e na Europa ocidental de meados da primeira metade do século XX. Por outro lado, o conceito de 'Estado integral' acaba também por redefinir profundamente sua concepção do partido revolucionário, que passa a ser denominado como 'moderno Príncipe' nos Cadernos do cárcere. Esta reconfiguração transforma profundamente a função do partido, sua forma de organização e sua estratégia. Outra coisa que muda radicalmente nos Cadernos do cárcere é a forma de se abordar a teoria do partido, substituindo o formalismo anterior pela apreensão da organização no interior do processo histórico da 'reforma intelectual e moral'.

\footnotetext{
8 A partir da publicação do livro de Christinne Buci-Glucksmann (1980) na segunda metade dos anos setenta a proposição gramsciana de 'Estado integral' passará a ser conhecida por 'Estado ampliado'.
} 
Então, o conceito de 'Estado integral' surge exatamente para identificar a nova morfologia do Estado capitalista moderno. Por este motivo, Gramsci o concebe como uma unidade dialética de 'sociedade civil' e de 'sociedade política'. Neste sentido, o que lhe interessa é a identificação da nova configuração assumida pelo Estado nacional europeu após a democratização do liberalismo. A irrupção da participação popular, por meio da expansão do direito de voto e da criação de grandes partidos operários, forjou uma nova configuração estatal, que permitiu a legitimação do poder político, em decorrência da unificação de coerção e consenso.

Fiel a seu método de atualização da 'filosofia da práxis', ao propor a noção de 'Estado integral' Gramsci acaba alterando também o conteúdo do conceito de 'sociedade civil'. Neste caso, ele se distancia tanto de Hegel (a sociedade civil como sendo constituída pelo "sistema de carecimentos" e de sua regulação) quanto de Marx (a sociedade civil como sendo formada pela estrutura de produção da vida material: ou seja, pela economia e pelas relações sociais de produção), identificando a 'sociedade civil' como uma nova instância das superestruturas, especializada na produção do consenso. Fica claro que Gramsci concebe a sociedade moderna como uma nova totalidade histórica composta por economia, Estado (no sentido restrito de 'sociedade política') e 'sociedade civil'. Consequentemente, buscando a atualização do conceito marxista de Estado, o novo conteúdo de 'sociedade civil' passa a nomear o conjunto de aparelhos privados de hegemonia que, em conjunto com a 'sociedade política', constitui a nova configuração histórica do 'Estado integral'.

E o que seria a 'sociedade política'? A 'sociedade política' seria o outro especular ou a imagem complementar da 'sociedade civil', que, na interação dialética com seu duplo, constituiria a nova configuração histórica do 'Estado integral'. Isto é, a 'sociedade política' coincidiria com aquilo que costumamos denominar "aparelho estatal" ou a soma dos mecanismos coercitivos que sempre fizeram parte do conceito de Estado (polícia, burocracia estatal, forças armadas etc.).

Num sentido bem preciso, o conceito de 'Estado integral' serviria para ressaltar a característica especial do Estado moderno, que já não se baseia apenas na coerção, mas que se apresenta "como um equilíbrio da sociedade política com a sociedade civil (ou hegemonia de um grupo social sobre toda a sociedade nacional, exercida por meio das organizações ditas privadas, como a igreja, os sindicatos, as escolas etc.)" (GRAMSCI, 2004, p. 84). Ou seja, as grandes transformações econômicas, políticas e sociais do século XX criaram uma rede de organizações (sindicatos, cooperativas, grandes partidos operários etc.) que passou a expressar o dissenso social. E isto, por conseguinte, acabou por criar um tipo de Estado que não se baseava única e exclusivamente na coerção, como se verificava nas formações sociais capitalistas do século XIX, mas que, pela primeira vez, aglutinava coerção e consenso por meio da instituição de um poder político legítimo, fundado no apoio ativo e passivo das grandes massas populares (base do conceito gramsciano de hegemonia).

Foi a percepção gramsciana pós-prisão da insuficiência da teoria marxista determinista do Estado que o qualificava meramente com base em seu conteúdo coercitivo (o Estado como um "comitê executivo" dos negócios da burguesia), que o levou a investigar essa nova conformação do Estado capitalista. A derrota do movimento operário ocidental (Itália, Alemanha, Hungria etc.) invalidou qualquer teoria determinista de Estado, fundada exclusivamente na coerção. $\mathrm{O}$ apoio popular ativo ao ordenamento burguês nas crises econômicas mais graves do início do século XX, impedindo a derrocada do capitalismo, pôs em relevo a existência de mecanismos capilares de difusão do consenso e de legitimação do poder político estabelecido.

Com efeito, o conceito de 'Estado integral' foi desenvolvido por Gramsci exatamente para substituir as teorias marxistas restritivas de Estado que, se é que tinham validade para o século XIX, já não davam conta de apreender a complexidade do poder político no século XX. Ou seja, o conceito de 'Estado integral' serviu para identificar precisamente a nova morfologia estatal que não se baseava mais apenas na coerção, mas que exigia a sua legitimação por meio da difusão de um amplo consenso popular no âmbito da 'sociedade civil', a partir dos organismos "privados" de hegemonia. 
E isto é fácil de ser compreendido, pois a luta política sob o 'Estado integral' exige não só a formulação de uma nova estratégia revolucionária, como impõe a proposição de uma forma-partido adequada à luta nas novas condições de socialização da política decorrentes da democratização do liberalismo. Afinal, num contexto de luta pela hegemonia, onde o exercício do poder político exige a conquista do consenso, o partido deve trabalhar em duas frentes. Primeiro, antes da conquista do Estado, o partido operário deve buscar construir a sua direção política sobre o conjunto da sociedade. Então, sob o 'Estado integral', o 'moderno Príncipe' deve realizar uma 'reforma intelectual e moral' da população, disseminando sua $W$ eltanschaunng como a matriz de conformação dos valores éticos, morais, econômicos e estéticos gerais ou universais. Até o momento em que a sua visão de mundo forneça os fundamentos da consciência do homem coletivo. Da mesma forma, e paralelamente, deve buscar construir a sua dominação política por meio da conquista posterior do aparelho de Estado.

Em última instância, foi esta nova mutação do Estado que impôs a necessidade da forma-partido qualificada por Gramsci como ‘moderno Príncipe’.

\section{O 'moderno Príncipe' - as razões do recurso à Maquiavel}

A identificação de uma nova tipologia do Estado burguês - isto é, do 'Estado integral' presente nas formações sociais do Ocidente capitalista desenvolvido - implica uma redefinição profunda da função do partido revolucionário, agora denominado por Gramsci de 'moderno Príncipe'.

A função do partido nas “Teses de Lyon” foi formulada com base numa concepção restritiva de Estado. Ou seja, o Estado era concebido em sua expressão meramente coercitiva ou apenas como 'sociedade política'. Neste caso, como demonstraram os bolcheviques na Rússia, o partido revolucionário tinha que ser firme, disciplinado e estar sempre pronto para o assalto direto ao aparelho de Estado. Com base neste quadro, Gramsci deriva a dupla função do partido: i) construir uma identidade política autônoma do proletariado e ii) liderar as classes trabalhadoras durante o processo revolucionário.

A concepção de 'Estado integral modifica substancialmente a formulação da função do partido. E isso, é claro, é uma decorrência direta do novo universo conceitual proposto por Gramsci nos Cadernos do cárcere, desenvolvido exatamente a partir do conceito de 'Estado integral'. Por conseguinte, ao traduzir a sua elaboração política anterior nesta nova linguagem, Gramsci destaca a função que agora compete ao partido como 'moderno Príncipe': i) avançar para além do projeto do príncipe-condottiere de Maquiavel, no sentido de construir uma nova 'vontade coletiva' nacional-popular que expresse o programa socialista e ii) realizar uma 'reforma intelectual e moral' das classes subalternas, visando elevar a sua visão de mundo ao nível de desenvolvimento da 'filosofia da práxis' (massivo processo de elevação cultural de massa)(GRAMSCI, 2001).

Gramsci chega mesmo a pensar na possibilidade de escrever um texto sistemático sobre o 'moderno Príncipe'. Como ele sugere, deveria ser algo semelhante ao livro de Maquiavel (O Príncipe), mas diferente em seu projeto histórico. Ao contrário do "secretário florentino", que se ocupou da formação da 'vontade coletiva' no alvorecer da civilização burguesa, quando da constituição do Estado unificado, interessava a Gramsci abordar a formação da 'vontade coletiva na fase histórica da revolução socialista. Essa ideia foi aventada posteriormente no Caderno 8, parágrafo 21, escrito entre 1931-1932: "Sob este título poderão ser recolhidas todas as indicações de Ciência Política que possam contribuir para a execução de um trabalho de Ciência Política que seja concebido e organizado segundo o modelo de $O$ Principe, de Maquiavel"(GRAMSCI, 2001, p. 951). Neste hipotético trabalho, utilizando-se de recursos literários e estilísticos apropriados, Gramsci pretendia expor o projeto político do 'moderno Príncipe' de modo "vivente", ao utilizar o mesmo recurso maquiaveliano de apresentar, por meio da forma dramática do "mito", o inteiro processo de constituição de uma nova 'vontade coletiva'. Provavelmente, tratou-se de uma menção meramente retórica, pois tal projeto nunca se realizou. 
Mas, afinal, por que razão Gramsci se refere a Maquiavel ao propor a versão final de sua teoria do partido? Qual é o sentido da metáfora do 'moderno Príncipe'? Provavelmente, duas razões principais levaram Gramsci a recorrer a figura/obra de Maquiavel para nomear a sua redefinição do partido revolucionário como 'moderno Príncipe'. A primeira é de ordem polêmica, já que a disputa pela herança maquiaveliana era travada na época por fascistas, liberais e comunistas. E, provavelmente, Gramsci também pode ser incluído neste contexto, buscando assimilar a figura de Maquiavel à luta cultural do momento. Contudo, o recurso a Maquiavel parece ter uma motivação mais estratégica, servindo para o seu projeto de atualização da 'filosofia da práxis'. Como se percebe ao analisar as notas mais sistemáticas dedicadas ao "secretário florentino", o seu objetivo principal é assimilar as contribuições da teoria política maquiaveliana (sobretudo, a sua concepção realista de política) à Ciência Política marxista, preparando-a para a luta política sob o 'Estado integral'. Em suma, de alguma forma, o que se depreende desta relação próxima de Gramsci com Maquiavel é o propósito de superar o determinismo economicista do marxismo, promovendo uma nova síntese dialética entre Maquiavel e Marx.

Então, por que a teoria do partido revolucionário aparece nos Cadernos do cárcere sob a rubrica do 'moderno Príncipe'? Muito provavelmente porque Gramsci compara a função do "príncipe" de Maquiavel com aquela do partido revolucionário: ou seja, ambos têm como função prioritária a fundação de novos ordenamentos políticos. O príncipe-condottiere visava constituir o Estado italiano unificado, já o 'moderno Príncipe' de Gramsci visa instaurar uma sociedade socialista. Apesar da semelhança enquanto construtores de novos ordenamentos, evidencia-se uma distinção fundamental em suas composições:

O moderno Príncipe, o mito-príncipe não pode ser uma pessoa real, um indivíduo concreto, só pode ser um organismo; um elemento complexo de sociedade no qual já tenha tido início a concretização de uma vontade coletiva reconhecida e afirmada parcialmente na ação. Este organismo já está dado pelo desenvolvimento histórico e é o partido político, a primeira célula na qual se sintetizam germes de vontade coletiva que tendem a se tornar universais e totais (GRAMSCI, 2001, p. 1.558).

\section{Uma nova estratégia - a 'guerra de posição'}

A constituição do 'Estado integral' no Ocidente, com a instauração de uma instância especializada na difusão do consenso ('sociedade civil'), inviabilizava definitivamente a aplicação da estratégia revolucionária empregada pelos bolcheviques em outubro de 1917. Essa estratégia fora vitoriosa na Rússia em função da vigência de um tipo restrito de Estado ('sociedade política'), marcado pela ausência ou pelo escasso desenvolvimento da 'sociedade civil'. Nessas condições, os sofrimentos provocados pela crise econômica e pela guerra minaram o consenso em torno do ordenamento tzarista, permitindo o "assalto frontal" ao aparelho de Estado, garantindo a vitória dos bolcheviques. Contudo, no Ocidente, em função da prevalência do 'Estado integral', a sociedade possui reservas de forças que inviabilizavam a aplicação deste tipo de estratégia revolucionária. Prova disso é que todas as tentativas de insurreição do proletariado na Europa Ocidental redundaram em derrotas. Essa constatação feita nos Cadernos do cárcere força Gramsci a propor a substituição da estratégia de “ataque frontal” ou de 'guerra de movimento' pela estratégia da 'guerra de posição'.

Esses dois conceitos da arte militar, que em sua acepção técnica indicam duas formas distintas de condução da guerra (isto é, guerra de assalto e guerra de trincheiras, respectivamente) são traduzidos por Gramsci para servir à arte política. Em resumo, a questão fulcral para a necessidade da mudança da tática empregada depende da existência do 'Estado integral'. Ou seja, o desenvolvimento do domínio hegemônico da burguesia, por meio da ampliação do Estado, fortaleceu muito a 'sociedade política', de tal forma que esta se tornou imune a um ataque direto ou frontal ao aparelho estatal. Portanto, é com base na identificação desta nova conformação histórica do Estado burguês que Gramsci reivindica a substituição da 'guerra de movimento' ("ataque frontal”) pela estratégia da 'guerra de posição' (conquista da hegemonia civil). No entanto, esta mudança estratégica não elimina a necessidade, em dados momentos cruciais, da utilização tática do "assalto frontal". 
Neste sentido, a 'guerra de posição' se constitui numa estratégia revolucionária que implica uma sucessão prolongada de enfrentamentos, abarcando primeiro a instância da 'sociedade civil' e depois a 'sociedade política'. Por conseguinte, uma das mais importantes tarefas táticas do 'moderno Príncipe' consiste em construir a hegemonia do proletariado no processo da disputa político-cultural travada nos organismos privados de hegemonia (sindicatos, partidos, escola, universidade etc.) que constituem a 'sociedade civil'. Esta disputa de hegemonia é a única forma de desconstruir o consenso difuso que legitima a ordem burguesa, substituindo-o por um novo 'senso comum' que estabeleça as bases ideológicas de um ordenamento socialista.

Enfim, a necessidade de substituir a 'guerra de movimento' ou "ataque frontal" pela 'guerra de posição' exige que o 'moderno Príncipe' torne-se dirigente já antes do assalto ao poder de Estado, conquistando, assim, o apoio majoritário das classes subalternas e desarticulando as fortalezas avançadas da burguesia presentes na 'sociedade civil'.

\section{Uma nova organização}

A adoção da estratégia da 'guerra de posição' impõe algumas reformulações à estrutura organizativa do partido revolucionário. Como regra geral nos escritos carcerários, Gramsci não apresenta um modelo sistemático da organização partidária, mas um conjunto de notas esparsas sobre a questão. No entanto, a sua interlocução crítica com Robert Michels, sua recusa do 'centralismo burocrático' e sua abordagem do "teorema das proporções definidas" " aplicados à composição dos partidos políticos permitem identificar os pontos fundamentais que deveriam nortear a estrutura do 'moderno Príncipe'. Com efeito, é por meio da análise dessas notas que se pode apreender as continuidades e descontinuidades que caracterizam a forma organizativa preconizada nas "Teses de Lyon" e aquela proposta nos Cadernos do cárcere.

A discussão com Michels gira em torno da refutação de sua propalada "lei de bronze da oligarquização". Como se sabe, ao analisar a dinâmica de funcionamento do SPD, Michels identificou fatores de ordem técnica, intelectuais e psicológicos que confluiriam para levar inevitavelmente à burocratização/oligarquização de qualquer forma organizativa complexa. Eis o dilema michelsiano: sem organização, a classe operária não pode atuar politicamente de modo eficaz, mas a própria constituição da organização (do partido operário) já instaura a cisão entre os interesses das massas e os interesses dos chefes. Essa tendência à burocratização/oligarquização, inerente a toda forma organizativa permanente, não pouparia nem mesmo o partido operário, então considerado como a forma mais democrática de partido político.

É evidente que o confronto com o sociólogo ítalo-germânico parte do reconhecimento de que sua obra principal ${ }^{10}$, apesar de seus limites teóricos e metodológicos (apontados nos Cadernos), coloca uma série de problemas que até aquele momento não haviam sido investigados pela tradição marxista. Dentre esses problemas, Gramsci destaca a questão da divisão entre dirigentes/dirigidos e a relação entre democracia interna ao partido e na esfera estatal.

A solução indicada por Gramsci à primeira questão reside na proposição de uma composição exclusivamente proletária do 'moderno Príncipe'. Segundo sua argumentação, a vigência da tese michelsiana (MICHELS, 1982) dependeria da composição interclassista dos partidos operários. Ou seja, o que levaria à cristalização de clivagens entre dirigentes/dirigidos seria a formação de partidos operários compostos por proletários, mas dirigidos por pequeno-burgueses. A constituição da organização em si

\footnotetext{
9 Trata-se de um teorema oriundo da Química utilizado para explicar a combinação de substâncias simples na formação de compostos mais complexos. Esse teorema foi incorporado por Maffeo Pantaleone (1857-1924) ao campo da economia pura, aparecendo em seu livro Principii di economia pura. É a partir deste livro que, por sua vez, Gramsci se apropria do "teorema".

10 Trata-se da obra Sociologia dos partidos políticos publicada originalmente em alemão em 1911.
} 
não seria o problema, pois se o partido é composto por uma única classe (isto é, se a sua referência social é homogênea), a divisão entre dirigentes/dirigidos seria algo puramente técnico (GRAMSCI, 2001).

Quanto à segunda questão, Gramsci faz uma distinção tácita entre democracia no interior do partido e democracia na esfera estatal. A democracia interna seria fundamental para estimular o debate e a vitalidade do partido, aparecendo como algo positivo para a educação política de seus membros. Contudo, uma vez tomadas as decisões democráticas via congressos e/ou outras instâncias deliberativas, a implementação das decisões táticas deveria ser feita por meio da aplicação do 'centralismo democrático'. Afinal, "para conquistar a democracia no Estado pode ser necessário - ou melhor, é quase sempre necessário - um partido fortemente centralizado" (GRAMSCI, 2001, p. 236). Assim, a limitação da democracia na esfera interna da organização teria uma função estratégica, pois serviria para intensificar a eficácia da intervenção política do partido.

Gramsci volta à questão da relação entre dirigentes/dirigidos quando contrapõe 'centralismo democrático' e 'centralismo burocrático'. O conceito de 'centralismo democrático' foi estabelecido por Lênin em 1902, no famoso livro intitulado Que fazer?, para indicar uma forma organizativa baseada na direção centralizada, na homogeneidade ideológica de seus membros e na rígida disciplina imposta pelo Comitê Central na aplicação da linha política decidida pelas instâncias deliberativas do partido. Ao que tudo indica, Gramsci ainda partilha desta concepção nos Cadernos do cárcere, defendendo o modelo organizativo estabelecido nas "Teses de Lyon", mas adiantando uma crítica sútil à burocratização na tomada de decisões no interior do partido. Ao inferir a possibilidade de uma degenerescência burocrática na condução do partido (que, de fato, efetivou-se sob o estalinismo), Gramsci estabelece uma distinção fundamental entre os dois tipos de centralismos, fundada na natureza da liderança partidária: "quando o partido é progressista, funciona democraticamente (no sentido de um centralismo democrático); quando o partido é reacionário, funciona 'burocraticamente' (no sentido de um centralismo burocrático)" (GRAMSCI, 2001, p. 1692).

Na concepção de Gramsci, o "centralismo democrático" é a forma ideal de organização porque é a única capaz de criar uma articulação orgânica entre "os impulsos oriundos de baixo com o comando pelo alto", possibilitando, desta forma, "uma contínua inserção dos elementos que brotam do mais fundo da massa na sólida moldura do aparelho de direção", assegurando assim a "acumulação regular das experiências" (GRAMSCI, 2001, p. 1634). Em contrapartida, o 'centralismo burocrático' seria exatamente o oposto disto, pois se constituiria como uma forma enrijecida de tomada de decisões, baseada na burocratização e na sedimentação da divisão entre dirigentes e dirigidos.

Finalmente, no que se refere à questão organizativa, Gramsci aborda a reestruturação do 'moderno Príncipe' por meio da aplicação do "teorema das proporções definidas" à investigação da composição ideal do partido. O objetivo de Gramsci é explorar, pela aplicação deste teorema, a estrutura composicional mais adequada para assegurar a resistência e a eficácia de atuação política do partido revolucionário. Neste sentido, o uso que Gramsci faz da aplicação deste teorema é sempre aproximativo, quase que metafórico. A composição ideal é investigada considerando-se os três estratos que compõem o partido. O primeiro estrato, composto por "homens comuns", "cuja participação é dada pela disciplina e pela fidelidade" (GRAMSCI, 2001, p. 1.733), constitui a maioria do partido (a massa partidária). Mas este grupo só se transforma em força política efetiva quando organizado, disciplinado e coordenado pela direção partidária. O segundo estrato, constituído pelos “elementos de coesão principal”, é formado pelos principais dirigentes e lideranças do partido. É este segundo grupo que organiza o partido no plano nacional, unificando as diversas "comunidades" (organizações locais, municipais, regionais etc.) numa força política unitária. A função deste grupo é a mesma daquela desempenhada pelos capitães na organização do exército. O terceiro estrato, constituído pelo "elemento médio", é responsável pela articulação dos outros dois grupos (primeiro e segundo estratos) e cumpre a função de fundir organicamente a massa de filiados com a direção partidária (GRAMSCI, 2001, p. 1734). Consequentemente, segundo o raciocínio de Gramsci, é a proporção adequada desses três estratos que vai permitir uma boa capacidade de resiliência diante dos ataques da reação e garantir a eficácia na intervenção política da organização. 


\section{Considerações Finais}

Após esse trabalho preliminar de reconstrução teórica do conceito gramsciano de partido revolucionário verifica-se que a proposição do 'moderno Príncipe' não se refere nem ao modelo sectário de partido estipulado pelo estalinismo, nem, tampouco, indica uma nova instauração do poder político, típica das primeiras décadas do século XX. O modelo proposto por Gramsci nos Cadernos do cárcere, que só existe como teoria, já que nunca foi efetivamente construído na prática, prescreve uma forma de partido comunista de massa, com direção centralizada e visceralmente vinculada ao projeto de elevação político-cultural das classes populares. Em suma, é um tipo de partido vinculado ao horizonte histórico das primeiras décadas do século passado, premido entre o modelo de partido de quadros leninista e o partido de inclusão de massas, que se tornaria disseminado na Europa ocidental após o fim da Segunda Guerra Mundial. Então, como caracterizar de modo sintético o conceito de 'moderno Príncipe'? Utilizando o enfoque da teoria marxista do partido, o conceito gramsciano de 'moderno Príncipe' pode ser sistematizado levando-se em consideração os três elementos principais que norteiam a concepção do partido revolucionário.

Em primeiro lugar, deve-se considerar como Gramsci concebia a questão do desenvolvimento da consciência de classe do proletariado. Esta é uma das questões fundamentais da teoria marxista do partido: como a consciência de classe se desenvolve entre as massas trabalhadoras? Pelo que vimos, quanto a esta questão, Gramsci fica entre as posições de Marx e de Lênin. O desenvolvimento de uma consciência política antagônica que aponte para a superação da sociedade de classes, resultaria da interação dialética entre as contradições do capitalismo, como previra Marx (percebidas no dia a dia, como o resultado das próprias condições de vida sob o capitalismo) e a educação política levada a cabo pelos intelectuais, como postulado por Lênin (nesta concepção, a consciência de classe provinha de fora, sendo transmitida aos operários pelos intelectuais).

A novidade instaurada por Gramsci encontra-se na concepção de 'intelectual orgânico'. Este tipo de intelectual é criado durante o processo de afirmação histórica das classes sociais fundamentais. Assim como a burguesia, durante o processo histórico de sua afirmação, criou os intelectuais que disseminaram a sua concepção de mundo para o conjunto da sociedade (vide o papel dos intelectuais iluministas durante o século XVIII), a afirmação estrutural do proletariado também criaria os seus intelectuais orgânicos, que então sistematizariam a nova concepção de mundo, difundindo-a entre as classes populares, criando, assim, uma nova matriz cultural que conformaria os valores, sentimentos, instituições etc. Além disto, é preciso lembrar que nas condições modernas de vigência do 'Estado integral' o principal destes intelectuais orgânicos do proletariado seria o próprio 'moderno Príncipe', concebido por Gramsci como um verdadeiro "intelectual coletivo".

Em segundo lugar, vem a questão da relação entre a classe e sua organização política. Ou seja, desde seus primórdios, a teoria marxista do partido sempre buscou demarcar a distinção entre referência social e organização política formal. Então, como a proposição do 'moderno Príncipe' concebe a relação entre o ser empírico da classe (classe em si) e a sua representação formal (classe para si)? Neste quesito também se pode observar a originalidade da perspectiva gramsciana. Desde as "Teses de Lyon", mas também nos Cadernos do cárcere, Gramsci concebe o partido como uma parte da classe, e não como um órgão da classe. O conjunto da classe proletária e de seus aliados constitui a referência social do 'moderno Príncipe', mas o partido formal é constituído apenas por uma parte da classe, aquela politicamente mais consciente e ativa. Contudo, também aqui se observa uma distinção sutil com a concepção leniniana do partido de vanguarda. Ou seja, Gramsci vai além de Marx, ao negar a identificação automática entre o partido e a classe, mas também supera Lênin ao recusar a distinção absoluta entre o partido real (o conjunto da classe) e o partido formal (a vanguarda de militantes profissionais). O 'moderno Príncipe' funcionaria como um elemento de intermediação entre a classe e a organização formal, buscando assimilar o máximo possível de sua referência social. 
Em terceiro lugar, vem a questão da estrutura organizativa do partido. Qual é a melhor forma de organização do partido? É evidente que essa não é uma questão abstrata, pois a escolha da forma organizativa é conformada pelas condições gerais da luta de classes (isto é, depende das condições objetivas de cada formação social). Também neste caso, a opção de Gramsci, que remonta ao período anterior à prisão, é pelo modelo de partido de massas. Nos Cadernos do cárcere, após a identificação da vigência do 'Estado integral', este modelo organizativo acaba se impondo ainda mais. Entretanto, mesmo neste caso (a proposta de um partido comunista de massa), Gramsci não abre mão da adoção do 'centralismo democrático'. Esta é uma elaboração que Gramsci absorve de Lênin e que permanece válida também nos escritos carcerários.

Em linhas gerais, esta é a caracterização sintética do 'moderno Príncipe'.

\section{Referências}

BUCI-GLUCKMANN, Christinne. Gramsci e o Estado. Rio de Janeiro: Paz e Terra, 1980.

GRAMSCI, Antonio. Quaderni del carcere. Torino: Einaudi, 2001.

. Escritos políticos. V. 2. Rio de Janeiro: Civilização Brasileira, 2004.

MICHELS, Robert. Sociologia do partido político. Brasília: Editora Universidade de Brasília, 1982.

NERES, Geraldo Magella. Gramsci e o "moderno Príncipe”: a teoria do partido nos Cadernos do cárcere. São Paulo: Cultura Acadêmica, 2012.

SILVA, Vania S. Vaz da. Como realizar a contextualização social das obras clássicas? (Comunicação Pessoal) 2019.

THOMAS, Peter. Rumo ao Moderno Príncipe. Revista Novos Rumos, v, 54, n. 2. p. 1-26, 2017.

WOOD, Neal. The Social History of Political Theory. Political Theory, p. 345-367, ago. 1978. 